\title{
Is Cash Flow per Share Paternalism by U.S. Accounting Rule Makers Warranted? An Empirical Study
}

\author{
Ning $\mathrm{Du}^{1} \&$ John E. McEnroe ${ }^{1}$ \\ ${ }^{1}$ School of Accountancy and Management Information Systems, DePaul University, Chicago, USA \\ Correspondence: Ning Du, Associate Professor, School of Accountancy and Management Information Systems, \\ DePaul University, One East Jackson Boulevard, Chicago, Il 60604, USA. Tel: 312-362-8308. E-mail: \\ ndu1@depaul.edu
}

Received: April 22, 2015

Accepted: May 13, $2015 \quad$ Online Published: August 19, 2015

doi:10.5430/ijfr.v6n4p1

URL: http://dx.doi.org/10.5430/ijfr.v6n4p1

\begin{abstract}
The Financial Accounting Standards Board (FASB) prohibits the reporting of cash flow per share (CFPS) information from the financial statements in fear of undermining the importance of the earning per-share metric. The objective of our research is to understand the validity of this argument by examining the effects of cash flow per share information on investors' judgments. We conducted a two by one experiment where we manipulate cash flow per share as the absence or presence of the statistic in the financial statements. Eighty-eight MBA students assumed the role of investors and participated in this study. We find that the cash flow per share information affects investors' reliance on cash flow information, but does not affect participants' performance evaluation. Our results are in support of including CFPS in the income statement as it may lead investors to pay more attention to cash flow information.
\end{abstract}

Keywords: cash flow, cash flow per share, accounting rule maker paternalism

\section{Introduction}

The ability to generate cash is vital to a business and reflects a critical measure of both the health of its operations and its financial performance. It is not uncommon for investors to rely on the cash flow of a company to value its worth. The absolute dollar amounts for cash flow are indeed included in financial statements, but the amount of cash flow per share information has historically been excluded from the financial Statements of United States publicly traded companies. Specifically, Financial Accounting Standards No. 95 (SFAS 95), Statement of Cash Flows, explicitly prohibits companies from reporting an amount of cash flow per share in the financial statements (FASB 2007, FAS95-9). Although certain other per-share data such as earnings and dividends are included in corporate financial reports (e.g., SEC Forms 10-K and 10-Q) and provide investors with a straight forward, albeit simplistic, benchmark for evaluation, the absolute dollar amounts for cash flow is not converted to a per-share basis in financial statements and compared to a stock's current price.

In spite of the prohibition by the Financial Accounting Standards Board (FASB), cash flow per share has been widely used in the calculation of investment valuation metric, such as price/cash flow ratio $(\mathrm{P} / \mathrm{CF})$. As explained in the basic investor primer Investopedia, "This metric compares the stock's market price to the amount of cash flow the company generates on a per-share basis" (Loth 2006). Some even argue that the P/CF ratio is a more reliable metric than price/earnings $(\mathrm{P} / \mathrm{E})$ to evaluate the investment attractiveness of a company's stock because the accrual based earnings is more susceptible to managers' manipulation. Given the popularity of cash flow per share information, especially in the popular investment advisory services, it is puzzling why the FASB still prohibits cash flow per share information from the financial statements despite the fact that many sophisticated investors employ it in their equity analysis.

As we will discuss in a later section, firms employing International Financial Reporting Standards (IFRS) face no such stricture, and many companies include cash flow per share in their financial statements. In the U. S. the cash flow per share information is provided by investment research services who often strongly recommend paying close attention to this number in investment valuation. For example, Value Line, the investment research firm, reports cash flow per share near the top of the annual statistical array and advises investors to interpret a rising (falling) trend as a 
signal of a company's strengthening (weakening) operations. Though the CFPS is widely used as a performance measure, the FASB is worried that investors may misinterpret this metric and substitute it for earnings per share.

Given this background, the objective of our research is to examine whether, when compared to earnings per share, the cash flow per share information may diminish the importance of net income. In other words, will cash flow per share draw investors' attention away from net income as the "bottom line" of a business and affect nonprofessional investors' evaluation of a company's financial performance? We conducted a two by one experiment where we manipulate cash flow per share as the absence or presence of the statistic in the financial statements. Eighty-eight graduate students assumed the role of investors and participated in this study. We find that the cash flow per share information affects investors' reliance on cash flow information, but does not affect participants' performance evaluation.

Unlike prior studies focus on the differences between different (direct or indirect) method of cash flow reconciliation (see Hales 2012 for a review; Hoder et al. 2010), we are the first to examine the effects of inclusion and exclusion of CFPS in the financial statements. This may provide ex ante evidence to the FASB and the International Accounting Standards Board (IASB) in their joint project to redefine how companies present their financial performance. One of the most controversial issues of this endeavor is on the proposed presentation of the Statement of Cash Flows.

We begin our study with a historical review of cash flow information and provide a summary of the attitudes and actions of the private and public sector accounting rule makers towards its disclosure in the financial statements of publicly traded entities. We also juxtapose the IASB's position on cash flow per share. We then continue with an analysis of how investment advisory sources present it in their metrics and also in what manner some non U.S. companies refer to it in other sections of the financial statements, followed by our research design, discussion of results, and summary and conclusions.

\section{Historical Perspective}

\subsection{General Accepted Accounting Principles (GAAP)}

The accounting phrase "cash flow" originally became common in the United States (U.S.) in the 1950's, and was rarely used before that time (Mason 1961, 31). As the term, in conjunction with its numerical use, became more popular in the financial statements of U.S., publicly traded entities, the accounting profession became worried that it would be misunderstood by users and perhaps overshadow the prominence of net income. Especially disconcerting to the profession was the use of the term "cash flow income" or "cash flow earnings." The Journal of Accountancy even published an editorial in 1958 titled, "Cash Flow Earnings-A Dangerous Concept." In this piece the author (Blough 1958, 77) stated "We have been much disturbed by the increased use in recent years of cash earnings or cash flow earnings by security analysts as an alleged improvement over the earnings or net income in accordance with generally accepted accounting principles." This "paternalistic" posture has persisted by the private sector accounting rule-makers for over fifty years, from the actions of the Accounting Principles Board to the Financial Accounting Standards Board. For example, in October 1963 Accounting Principles Board Opinion No. 3, (APB 3), The Statement of Source and Application of Funds, was issued. The Opinion stated (FASB 2010, 205):

Misleading implications can result from isolated statistics in annual reports of 'cash flow' which are not placed in proper perspective to net income figures and to a complete analysis of source and application of funds. "Cash flow" and related terms should not be used in annual reports in such a way that the significance of net income is impaired, and 'cash earnings' or other terms with a similar connotation should be avoided. The Board regards computations of "cash flow per share" as misleading since they ignore the impact of cash expenditures for renewal and replacement of facilities and tend to downgrade the significant economic statistic of 'earnings per share.'

Accounting Principles Board Opinion No. 19 (APB 19), Reporting Changes in Financial Position, which was issued in March 1971, used a very similar admonishment, "The Board strongly recommends that isolated statistics of working capital or cash provided by operations, especially per share amounts, not be presented in annual reports to shareholders" (FASB 2010, 503). This attitude continued with Statement of Financial Accounting Standards No. 95 (SFAS 95), Statement of Cash Flows, issued in November 1987, which specified, "Financial statements shall not report an amount of cash flow per share. Neither cash flow, nor any component of it is an alternative to net income as an indicator of an enterprise's performance, as reporting per share amounts might imply" (FASB 2007, FAS95-9). In its Basis for Conclusions section the Board stated that it considered whether cash flow per share should be reported but again concluded that it would "falsely" imply that the statistic or some component of it is a possible substitute for earnings as a performance measure (FASB 2007, FAS95-25). This prohibition continues in the Codification, for 
230-10-45-3 states, "Financial statements shall not report an amount of cash flow per share. Neither cash flow nor any component of it is an alternative to net income as an indicator of an entity's performance, as reporting per-share amounts might imply."

\subsection{Securities and Exchange Commission (SEC)}

After the release of APB 19, the SEC issued Accounting Series Release No.142, (ASR 142) Reporting Cash Flow and Other Related Data, in March 1973 (SEC, 1976). It stated that the use of "cash flow per share" data in prospectus statements and in the "Financial Highlights" or "Presidents Letter" section of annual reports in conjunction with certain non GAAP financial data presentations "appear designed to decrease the credibility of conventional financial statements as a measure of business activity" and the "variation in form and purposes of such data creates confusion" (SEC 1976, 250). The reason cited was that these metrics did not have precise definitions and might be interpreted differently by various users. It added that the presentation of "cash flow" information on a per share basis "compounds confusion." ASR 142 went on to state, "Most importantly, such a presentation emphasizes the implication that cash flow is more meaningful than net income as a measure of performance, particularly when a per share figure is included in the 'Financial Highlights' section of a report" (SEC 1976, 252). Accordingly, it concluded, "per share data other than that relating to net income, net assets and dividends should be avoided in reporting financial results" (SEC 1976, 253). Subsequently, an SEC ruling, Regulation G on non-GAAP financial disclosures was released in 2003 (SEC 2003a), which basically requires that firms who disclose non-GAAP disclosures provide a presentation of the most directly comparable GAAP measure and a reconciliation of the two disclosures. However, footnote 11 of the Regulation reads:

While we have not included a prohibition on per share non-GAAP financial measures in Item 10 of Regulation S-K or Item 10 of Regulation S-B, per share measures that are prohibited specifically under GAAP or Commission rules continue to be prohibited in materials filed with or furnished to the Commission. See, for example, the prohibition on cash flow per share in paragraph 33 of FASB Statement No. 95, Statement of Cash Flows.

This prohibition was reiterated in a June 132003 SEC release dealing with "frequently asked questions, such as "if a part of Item 10 of Regulation S-K overruled or superseded by ASR. No 142". The SEC responded, “...the GAAP prohibition on presenting cash flow per share is maintained and per share measures of liquidity continue to be prohibited." (SEC 2003b, 6) Accordingly, it appears that the SEC would not permit a U.S. registrant to provide supplementary cash flow per share information.

\subsection{International Financial Reporting Standards (IFRS)}

"Although U.S. GAAP specifically prohibits the presentation of cash flow per share, or similar information, in the financial statements, IFRS does not have a similar restriction" (SEC 2011, 14). Under IFRSs, there is no explicit prohibition of reporting cash flow per share, and IAS 7, which deals with the statement of cash flow (IASB 2010), does not refer to the disclosure of this metric. Accordingly, IAS 33, which provides guidance for earnings per share, allows an entity to choose to voluntarily report cash flow per share (IASB 2003). To help companies interpret the flexibility in cash flow per share reporting, the accounting firm Grant Thornton issued a document in August 2012 entitled "IAS 7: Statement of Cash Flows-a guide to avoiding common pitfalls and application issues" (Grant Thornton 2012): (Note 1)

Some entities may wish to disclose a 'cash flow per share' amount. This is not specifically addressed in IFRS and so judgment is needed to determine the appropriate accounting policy. Relevant guidance may be found in IAS 33 'Earnings Per Share' (IAS 33), which envisages that an entity may choose to disclose an amount per share that is based on a different amount than the earnings figure required by IAS 33. In such

cases, IAS 33.73 requires specific disclosure, including details of how the numerator is calculated, together with a reconciliation to a related line item in the statement of comprehensive income.

\subsection{Proprietary Cash Flow per Share Metric Disclosures}

Despite the cash flow per share sanctions by the private and public sector accounting rule-making bodies, as mentioned previously, investment research firms strongly endorse its use as a performance metric. For example, consider this quote from Value Line, (Gallagher, 2009)

It is often said that "cash is king" in business. Thus a company's cash can be very telling when measuring its healthy. Accordingly investors should pay close attention to the "cash flow" line (sometimes referred to as the "Value Line") on the Value Line page. 
The publication then goes on to define the figure as net income plus non-cash charges (depreciation, amortization, and depletion) less preferred dividends. This number is then divided by all of the outstanding common stock. It goes on to state that it is an indicator of the company's internal cash generating ability, and states that positive growth is associated with strength and negative trends with weakening operations. The former trends should be regarded favorably as increasing capacity for share buy backs and dividends. It also compares the company's stock price/ cash flow per share multiple to the firm's price/earnings ratio and if the cash flow multiple is less, it might indicate an advantageous investment. We reviewed three other investment research service sites, Thomson One, Standard and Poor's Net Advisory, and Moody's Mergent Digitilized Archive Collection and they all had some cash flow per share metrics.

\section{Hypothesis Development}

Investors rely on various valuation ratios to judge the attractiveness of an investment opportunity (i.e. whether a stock price is too high, reasonable, or a bargain), and make investment decisions such as whether to buy, hold or sell a particular stock. Cash flow per share (CFPS) has been widely used in the calculation of investment valuation metric, such as price/cash flow ratio $(\mathrm{P} / \mathrm{CF})$, which provides a straightforward benchmark to compare to a stock's current price. The FASB is worried that including CFPS in the financial reports may increase its salience and undermine the importance of earnings per share (EPS) and fears that investors may view CFPS as a more meaningful performance measure. However, it is not clear that the CFPS information itself may affect investors' judgments on corporate performance. In other words, do investors' judgments differ when the CFPS information is included or excluded in the financial statements?

We rely on the model proposed in Maines and McDaniel (2000) as a theoretic framework to investigate the effects of cash flow per share (CFPS) information. Maines and McDaniel (2000) proposed a three-stage model to understand how financial information affects investors' judgments and decision-making. The three stages include acquisition, evaluation and weighting of financial information. Their model suggests that financial information may affect judgments at any stage and lead to differences in decision making. They test this model in an experiment where MBA students evaluate different reporting formats of comprehensive income. They assigned different reporting format to different groups and find that all the groups are able to read financial information included in the financial statements and correctly assess its visible characteristics (p185, Maines and McDaniel 2000) but the weighting of the information differs across the groups. Their results show that the reporting format has no effect on investors' acquisition and evaluation of OCI information but does have an effect on the weighting of OCI information. They conclude that different pieces of financial information may affect different stage of decision making due to non-professional investors' limited understanding of financial analysis.

We examine the impact of cash flow per share information from two perspectives. First, we focus on its direct effects by examine how it affects investors' evaluation of corporate performance. As investors care about the profit or loss of a company, the "bottom line" of a company remains to be its earnings. Most investors have adequate knowledge about the financial statements and understand the difference between accrual and cash accounting. Provided with a set of financial statements, they should have no difficulty in obtaining the absolute dollar amount of cash flow, assess its effects and incorporate that information in their evaluation. The CFPS, as a standardized metric (dividing the net cash flow by the total number of outstanding shares), is very useful when investors compare across different companies, but this metric may not provide any additional information for evaluation within the same company. This argument suggests, to the extent that investors evaluate one single company, the inclusion of CFPS (cash flow per share) in the financial statements may not make much difference on investors' judgments. Thus, our first hypothesis is stated in null form:

H1: The evaluation of corporate performance does not differ when the financial statements include CFPS information or exclude this information.

However, a lack of difference in investors' judgments may be due to other reasons: first, investors may highly value earnings as the performance measure and simply ignore the CFPS metric when it's provided; second, when CFPS is not provided, these investors may be sophisticated enough to convert the absolute dollar amount of net cash flow in the cash flow statement to the standardized CFPS metric. To understand the underlying judgment process, we examine how individual investors weight the information in the cash flow statement. Specifically, we suggest that by including the CFPS information in below EPS in the income statement, the CFPS information increase the salience of cash flow information, and direct investors' attention to information in the cash flow statement. Thus, the inclusion of CFPS information leads investors to place more weight on the cash flow statement than excluding this information. Our second hypothesis states as follows: 
H2: The weight on cash flow information will be higher when the financial statement include the CFPS information than when the CFPS is excluded.

We do not expect that the differential weight on cash flow information lead to judgment differences of corporate performance as long as the cash flow and accruals are of the same sign (i.e., +/+, -/-) (see Hoder et al. 2010). In a recent study, Hoder et al. (2010) find that the current structure of the indirect-approach statement of cash flows impedes investors' ability to learn the time series properties of operating cash flows and operating accruals. Specifically, they observed higher forecast errors and dispersion in the current indirect format than the "reverse-process" format which starts with operating cash flows and adds changes in accruals to arrive at net income and poor forecasting performance when the cash flows and accruals are offsetting (i.e., "mixed sign") than when both are of the same sign (Hoder et al. 2010). Thus, we believe the differential weight may lead to different performance judgments only if the pattern of cash flows and accruals differ in their signs $(+/-$ or $-/+)$.

\section{Method}

\subsection{Participants}

The participants are 88 graduate students from a large private university in the United States. These students are currently enrolled in the MBA program. Students volunteered to participate in response to in-class announcements for extra course credit. Demographic information collected at the end of the experiment indicates that most participants are likely to have the necessary knowledge and experience to complete the task. For example, the majority of participants have both work and investment experience. On average, the participants have about 2.52 years of working experience and 2.09 years of investment experience. In addition, we asked them to indicate how much knowledge they have about cash flow statement as well as the level of difficulty in evaluating the case. The mean rating for knowledge is 8.51 on an 11-point scale (1 being very little, 11 being a great deal) and for difficulty is 5.6 ( 1 being not difficult and 11 being very difficult). These ratings suggest that participants are relatively confident about their understanding of cash flow, a result we surmise reflects the general competence of individual nonprofessional investors. Among the participants 46 are males and 42 are females, representative of the graduate school cohort.

\subsection{Procedure and Task}

We asked the participants to assume the role of an investor and evaluate the attached case materials contain financial information about XYZ Exports, Ltd. Their primary goals while completing this case are to assess the company's stock price performance and to evaluate the company's financial statements. The case materials include the background information as follows:

XYZ Exports, Ltd. (the "Company") is a mid-sized specialty manufacturer of tools and is headquartered in the Midwestern U.S. The Company ships first-rate tools to carpenters, contractors, production facilities and fabricators across North America. XYZ's products are largely sold directly to the end users, but the Company also sells to select distributors in certain high-demand markets.

XYZ Exports, Ltd. is a member of Industry M. Industry M consists of approximately ten, small- to medium-sized companies. Analysts frequently rely on the return on assets ratio and the profit margin on sales ratio to assess the financial performance of firms in this industry. The following table reports these ratios for 2012 and 2011 for both XYZ and the industry:

\begin{tabular}{|c|c|c|c|c|}
\hline & \multicolumn{2}{|c|}{ Return on Assets (ROA) } & \multicolumn{2}{|c|}{ Profit Margin on Sales } \\
\hline & $\underline{2012}$ & $\underline{2011}$ & $\underline{2012}$ & 2011 \\
\hline$X Y Z$ & $1.61 \%$ & $1.50 \%$ & $6.70 \%$ & $5.92 \%$ \\
\hline Industry Average & $1.55 \%$ & $1.50 \%$ & $5.93 \%$ & $5.90 \%$ \\
\hline
\end{tabular}

Finally, we provided excerpts from the 2012 audited financial statements, including income statement, balance sheet and cash flow statement (see Appendix A).

In addition, we provide the following press release: 


\section{Headline: XYZ Exports Announces 2012 Annual Results}

Text: XYZ Exports, Ltd. today reported net income of \$1,000,000 for the fiscal year ended December 31, 2012 versus $\$ 849,000$ in 2011 , an increase of $17.8 \%$.

The company also reported sales of \$200,000,000 for the year ended December 31, 2012 versus $\$ 192,123,000$ in 2011, an increase of $4.1 \%$.

Earnings per share were $\$ 1.00$ and cash flow per share was $\$ 21.50$ for the year 2012.

\subsection{Independent and Dependent Variables}

We manipulated the independent variable at two levels, with cash flow per share (with CFPS) and without cash flow per share (without CFPS). In the without cash flow per share condition, we deleted the cash flow per share of $\$ 21.50$ information in the press release as well as the income statement. Our dependent variables are the strength of company performance, likelihood to invest in the company, the extent of reliance on EPS and the weight assigned to financial statements.

\section{Results and Analysis}

To check the cash flow per share manipulation, we asked the participants whether the cash flow per share information is provided or not provided. All participants checked the correct answer. Hypothesis One is in the null form and states that the cash flow per share information does not affect participants' evaluation of performance. To test this hypothesis, we asked the participants two questions: 1) How strong is the company's performance (1 being very weak, 11 being very strong)? 2) How likely are you to invest in XYZ Exports, Ltd (1 being unlikely, 11 being highly likely)? We compared the means and conducted t-tests for the results, which are presented in the table below. For the first question, the mean rating is 7.27 in without cash flow condition and 7.65 in with cash flow condition $(F(1,86)=1.09, \mathrm{p}=0.30)$. For the second question the mean rating is 7.00 in no cash flow condition and 6.65 in with cash flow condition $(\mathrm{F}(1,86)$ $=0.61(\mathrm{P}=0.44)$. The results show that the two ratings do not differ across the two conditions: with cash flow per share and without cash flow per share and suggest that cash flow per share information does not affect the participants' evaluation of company performance. Thus, Hypothesis One is supported.

\begin{tabular}{lccccc}
\hline & With & Without & Mean & F & \\
& CFPS & CFPS & Difference & $(1,86)$ & $\mathrm{p}$ \\
\hline Performance Strength & 7.65 & 7.27 & 0.38 & 1.09 & 0.30 \\
\hline Likelihood to Invest & 6.65 & 7.00 & 0.35 & 0.61 & 0.44 \\
\hline Reliance on EPS & 5.83 & 7.20 & 1.37 & 6.16 & 0.02 \\
\hline Weight on Cash Flow Statement & 51.75 & 42.52 & 9.23 & 4.46 & 0.04 \\
\hline
\end{tabular}

Hypothesis Two states that participants will rely more on cash flow statement in the with CFPS condition than the without CFPS condition. To test this hypothesis, we ask the following two questions: 1) Please indicate to what extent you rely on Earnings per share (EPS) information for your evaluation of XYZ (1 being very little, 11 being very much); 2) In your evaluation of the company, how did you weight the income statement and cash flow statement? Please give a percentage to the items below (Note: all two percentages should add up to $100 \%$ ). We find that the reliance on EPS rating is significantly lower when participants are provided with cash flow statement (mean $=5.83$ ) than those without cash flow statement (mean $=7.20)(\mathrm{F}(1,86)=6.16, \mathrm{p}=0.02)$. This suggests that participants rely more on EPS information if the cash flow per share information is excluded from the income statement. More interestingly, we find that cash flow per share information appears to direct attention to the cash flow statement as participants place significantly higher weight on cash flow statement when CFPS information is included (mean $=51.75 \%$ ) than excluded $($ mean $=42.52 \%)(\mathrm{F}(1,86) \mathrm{p}=0.04)$. Thus, Hypothesis Two is supported.

\section{Conclusion}

Despite the sanction of the FASB, the cash flow per share information is a popular performance metric among investors. This study was intended to understand how the CFPS information affects investors' judgments. We conducted an experiment where we manipulated cash flow per share as the absence or presence of the statistic in the financial statements. Results from the experiment suggest that the cash flow per share information affects investors' reliance on cash flow information, but does not affect participants' performance evaluation. Our results support the inclusion of CFPS in the income statement as it may lead investors to pay more attention to cash flow information. 
To the extent that a company has similar earnings information, but different cash flows, the inclusion of CFPS may lead investors to examine the differences in cash flow statements and thus, reach different conclusions, about a company's performance.

As the absolute dollar amounts for cash flow is presented in the financial statements, investors may easily convert this number to a per-share basis and use it as a valuation metric. A knowledgeable investor may include or exclude different items in the calculation of cash flow, and derive different amounts of CFPS. For example, some may use cash flow from operations in calculating CFPS, while others may use operating cash flows before working capital changes. This inconsistency may lead to different judgments in evaluating the same investment option. To the extent that different investment advisory groups use different definitions of CFPS, it will be difficult for nonprofessional investors to assess the real worth of an investment option. Therefore, we believe it is to the advantage of the investment community if the FASB requires a standardized reporting of CFPS in the financial statements.

In this study, we provided participants with the same financial statements, so it is not surprising that we find that the participants do not differ in their ratings of company performance. Future studies should examine the impact of CFPS by holding earnings information constant and varying the absolute amount of cash flows. In addition, we hold the sign of the earnings and cash flow amounts the same (++). Future studies should investigate whether inconsistent sigs in the financial statements, such as positive earnings and negative cash flow or vice versa, may affect investors' judgments of corporate performance.

\section{References}

Blough, C.G. (1958, October). Cash flow earnings-A dangerous concept. Journal of Accountancy, 77-78.

Financial Accounting Standards Board. (FASB). (2007). Original Pronouncements Accounting Standards Volume I, Statement of Financial Accounting Standards No. 95, Statement of Cash Flows. Stamford:FASB.

(2010a). Accounting Standards Volume I Accounting Principles Board Opinion No. 3, The Statement of Source and Application of Funds. Norwalk: FASB.

. (2010b). Accounting Standards Volume I Accounting Principles Board Accounting Principles Board Opinion No. 19, Reporting Changes in Financial Position.

Gallagher, R. (2009). Taking a look at the "Value Line." Value Line, October 9.

Grant Thornton. (2012). IAS 7: Statement of Cash Flows-a guide to avoiding common pitfall and application issues, August.

Hales, J., \& Orpurt, S.F. (2012). A review of Academic Research on the Reporting of Cash Flows from Operations, Working Paper, Georgia Institute of Technology.

Hodder, L., Hopkins, P.E., \& Wood, D.A. (2008). The Effects of Financial Statement and Informational Complexity on Analysts' Cash Flow Forecasts. The Accounting Review, 83(4), 915-956.

Hodge, F.D., Hopkins, P.E., \& Wood, D.A. (2008). The Effects of Financial Statement Information Proximity and Feedback on Cash Flow Forecasts. Contemporary Accounting Research.

IASB. (2010). International Accounting Standard 7 Statement of Cash Flows IFRS Foundation.

International Accounting Standards Board (IASB). (2003). International Accounting Standard 33. Earnings per Share. IFRS Foundation.

Loth, R. (2006). Investment valuation ratios: Price/ Cash flow ratio. Investopedia.

Maines, L., \& McDaniel, L. (2000). Effects of comprehensive-income characteristics on nonprofessional investors' judgments: The role of financial statement presentation format. The Accounting Review, 75(2), 179-207.

Mason, P. (1961). Accounting Research Study Number Two, 'Cash Flow' Analysis and the Funds Statement. AICPA: New York.

Securities and Exchange Commission (SEC). (1976). Accounting Series Releases. Release N. 142. Reporting Cash Flow and Other Related Data. Washington: SEC.

. (2003a). Final Rule: Conditions for Use of Non-GAAP Financial Measures. [Release No. 33-8176; 34-47226;FR-65;FILE NO. S7-43-02] RIN 3235-A169.

. (2003b). Frequently Asked Questions Regarding the Use of Non-GAAP Financial Measures, June 13.

(2011). Work Plan for the Consideration of Incorporating International Financial Reporting Standards into the Financial Reporting System. A Comparison of U.S. GAAP and IFRS. November 16. 


\section{Note}

Note 1. A brief search for cash flow per share disclosures indicate that companies under IFRS report this statistic in different ways: 1) Avino's (British Columbia) new release of its first quarter, 2014 financial results, including highlighted cash flow from operations per share of $\$ .05,2$ ) WSP Global Inc. (Canada) Management Discussion and Analysis of its 2013 earnings in which it disclosed 2013 "funds from operations per share of \$2.39 (Canadian dollars) which it compared to 2012's \$2.29 per share, (it also disclosed a "free cash flow per share" statistic, and 3) Goldcorp's (Canada) disclosure of its 2012 “operating cash flows before working capital changes" of \$2.97 per share (Canadian dollars) as compared to 2011 's $\$ 3.35$ per share. So, it appears that certain firms are disclosing the statistic in various related forms.

\section{Appendix One}

\section{Income Statement}

XYZ, Ltd.

For the Year Ending 12/31/2012

(In Thousand)

Sales

Cost of goods sold

Depreciation expense

Insurance expense

Wage Expense

Net Income

Earnings per share

Cash Flow per share

(based on cash from operations)
$\$ 200,000$

$(123,000)$

$(15,000)$

$(11,000)$

1,000

$\$ 1.00$

$\$ 21.50$ 


\section{Comparative Balance Sheet}

XYZ, Ltd.

(In Thousand)

\section{2}

2011

$\begin{array}{lll}\text { Cash } & \$ 4,000 & \$ 14,000 \\ \text { Accounts receivable } & 25,000 & 32,500 \\ \text { Prepaid insurance } & 5,000 & 7,000 \\ \text { Inventory } & 37,000 & 34,000 \\ \text { Fixed assets } & 316,000 & 270,000 \\ \text { Accumulated Depreciation } & (45,000) & (30,000) \\ \text { Total assets } & 342,000 & 327,500 \\ & & \\ \text { Accounts payable } & \$ 18,000 & \$ 16,000 \\ \text { Wages payable } & 4,000 & 7,000 \\ \text { Note payable } & 173,000 & 160,000 \\ \text { Capital stock } & 88,000 & 84,000 \\ \text { Retained earnings } & 59,000 & 60,500 \\ \text { Total Liabilities \& Equity } & 342,000 & 327,500\end{array}$

Additional Information:

- During $2012 \mathrm{ABC}$ declared and paid dividends of $\$ 2,500$

- During 2012, $\mathrm{ABC}$ paid $\$ 46,000$ in cash to acquire new fixed assets.

- The accounts payable was used only for inventory.

- No debt was retired during 2012.

\section{Statement of Cash Flow for the Year Ending}

$\underline{12 / 31 / 2012}$

\section{(Indirect Method)}

(In Thousand)

Cash Flow from Operations:

Net Income

Depreciation Expense

15,000

$\Delta$ Accounts receivable

7,500

$\Delta$ Prepaid insurance

2,000

$\Delta$ Inventory

$-3,000$

$\Delta$ Accounts payable

2,000

$\Delta$ Wages payable

$-3,000$ 